\title{
The Development of Learning Materials for Multicultural-Based Civic Education to Improve Students' Learning Achievements
}

\author{
Kurniawan $^{1,}$ Wachidi ${ }^{2}$, Turdjai ${ }^{2}$, Wasidi ${ }^{2}$ \\ ${ }^{1}$ Institut Agama Islam Negeri Curup \\ ${ }^{2}$ Universitas Bengkulu \\ kuriaincurup@gmail.com
}

\begin{abstract}
The research objective is to produce learning materials for multicultural-based Civic Education to improve students' learning achievements. The development of this learning material applies the ADDIE model. The subjects of this study were four experts as validators, and at the evaluation stage, a quasi-experiment was carried out with a sample of 90 students. The population of quasi-experiment is students of Teacher Education of Elementary School Study Program of State Islamic Institute of (IAIN) Curup. The sample was selected through a purposive technique. The research instruments are validation sheets, practicality sheets, and achievement tests. The achievement test data were analyzed using covariate analysis (ANCOVA). The data analysis results state that multicultural-based Civic Education learning materials have met a high level of validity based on expert reviews and empirical tests. It has also met a bigh level of practicality. The multicultural-based Civic Education learning materials have met a high level of effectiveness, and the learning achievements of students who are taught with these learning materials are better than the learning achievements of students who are taught conventionally.
\end{abstract}

Keywords: Civic Education, Learning Achievement, Multicultural, Learning Materials

\section{INTRODUCTION}

Multicultural education innovation programs build a culture that accommodates the spirit and multicultural values in the environment of Islamic institutions (Hifza, Antoni, Syakhrani, \& Hartati, 2020). Civic Education or Pendidikan Kewarganegaraan (PKn) is one of the compulsory courses at the Faculty of Education (Tarbiyah) at State Islamic Institute of (IAIN) Curup, Indonesia. It was aimed to educate the character of the nation. The end of its character and implementation in multicultural societies becomes a national and global issue (Thoriquttyas \& Rohmawati, 2017). The real challenges facing society today about Indonesia's increasingly culturally diverse student population. Multicultural education can be appropriately implemented and shows active, more democratic learning achievements, and there is no tendency to favor one of the dominant group cultures (Utami \& Cahyono, 2018).

Indonesian society is a plural society consisting of various nations, both religious, rationalism, traditions, and has language and socio-cultural patterns that are not the same as others (Feli, Islam, \& Jadid, 2019). As a country with various tribes, groups, cultures, and religions, Indonesia can be referred to as a multicultural society (Syahbudin \&Hanafi, 2018). The implementation of multicultural-based learning is based on multicultural learning objectives. Learning is intended to develop students' ability to perceive different cultures and be optimistic about cultural, racial, and ethnic differences (Rochana, 2020). 
The integration of pluralism and multicultural education is applied through the development of teaching materials, the application of suitable methods, the construction of knowledge, the reduction of prejudices, and the evaluation of learning. The application of multicultural education is that radicalism can be prevented by integrating pluralism and multiculturalism in the sociological education curriculum (Syahrul, 2021). Multicultural-based education involves all learners regardless of ethnicity, race, culture, and religion. Multicultural-based education requires awareness of each ethnicity to recognize each other, respect cultural and religious diversity (Marhayani, Kariadi, \&Yanti, 2017).

Indonesia is a country rich in culture. Various religions and cultures from different provinces are now seen living side by side in many places. One of the biggest questions facing Indonesia today is how to deal with culturally diverse citizens and then promote unity (Muslichah, 2018; Hadiwijaya \& Adi, 2018). Multicultural education plays a crucial role. Students can develop optimally (Wahab, 2007). Through multicultural education is the right learning approach in the implementation of education in Indonesia. Multicultural education does not stand alone in the subject but is integrated into all subjects by incorporating multicultural values (Endah, 2016).

With the diversity of culture and local wisdom, and based on the author's identification as a Civic Education lecturer at IAIN Curup, there are student problems during Civic Education learning. The problems are that during PKn learning takes place, students are passive, and lecturers dominate learning activities. Students have low self-efficacy in following Civic Education learning. Students have low social skills while interacting in Civic Education learning. Appropriate learning materials can increase students learning achievements by elevating local wisdom as a starting point of learning. Therefore, it takes multicultural-based Civic Education learning materials. This research aims to produce learning materials for multicultural-based Civic Education that are valid, practical, and effective to improve students' learning achievements.

\section{METHOD}

Based on the purpose of research, this research belongs to the type of development research. The focus of this development is multicultural-based Civic Education learning materials. In this research, the development model used is ADDIE development design (Analysis-Design-DevelopmentImplementation-Evaluation). Learning materials are suitable if they meet three criteria, i.e., valid, practical, and effective (Plomp \& Nieveen, 2013). The validity aspect is associated with two things, namely, whether the model developed is based on a robust theoretical rationale; and whether there is internal consistency. Aspects of practicality can only be met if experts and practitioners state that what is developed can be applied, and reality shows that what is developed is applicable. The level of practicality related to the development of instruments in learning materials is measured by looking at whether lecturers (and other experts) consider that the material is accessible and can be used by lecturers and students. Teaching materials are said to be practical if experts and practitioners state that the model can be applied in the field, and the level of implementation of the model belongs to the category of good.

Parameters measure effectiveness as experts and practitioners based on their experience state that the model is good and operationally the model delivers results as expected. The effectiveness of teaching material is usually seen from the potential effects of quality social skills and self-confidence, attitudes, and motivation of learners. Two aspects of effectiveness must be met by a learning material, namely experts and practitioners based on their experience, stating that 
the teaching material is adequate. Operationally the teaching material provides the expected results (Widada et al., 2019). The instruments are used to test validity, practicality, and effectiveness, namely instruments of validity, practicality, and effectiveness.

The subjects of this study were four experts as validators, and at the evaluation stage, a quasi-experiment was carried out with a sample of 90 students. The sample was selected through a purposive technique from students of the Teacher Education of Elementary School Study Program at IAIN Curup. Two groups of students were taught with multicultural-based Civic Education learning materials and other groups with conventional learning materials. Data collected through the instrument of validity, practicality are analyzed with descriptive statistics, i.e., percentages. The data of the learning achievement test are analyzed with analysis of covariate (ANCOVA).

\section{FINDING}

\section{Analysis Stage}

\section{Results of Student Needs Analysis}

Based on the analysis of the students of IAIN Curup need for learning materials for Civic Education, students do not like conventional learning materials. They prefer multicultural-based learning materials. Students hope that the content/material of Civic Education learning materials is multicultural-based. Students are less following conventional Civic Education books. Reading text in conventional Civic Education learning materials is monotonous and difficult to understand. The image on the cover of conventional Civic Education learning materials is not attractive. The images on the contents of conventional Civic Education books are not attractive. The typeface used in conventional Civic Education learning materials needs to be corrected because it is less clear. The font size on conventional Civic Education learning materials needs to be corrected, the images need to be improved, and the lecturers use conventional monotonous learning materials. By the way, lecturers teach with a learning model using conventional Civic Education is less attractive. The material in conventional Civic Education courses is difficult to understand.

The difficulties faced by students in learning the material are due to the lack of contextually based on the heterogeneous of Indonesian society. Difficulty in understanding the material is also caused by conventional Civic Education learning materials being too textual. Students tend to be passive during the process of conducting this lecture. Students only carry out activities following what the lecturer ordered. Student activities often do not follow the instructions of lecturers. They hold smartphones. The language used in conventional Civic Education learning materials is not easy to understand. The language used in conventional Civic Education lecture teaching materials is also difficult to understand. It was used in conventional Civic Education lecture teaching materials when viewed from excellent and correct spelling Indonesian, has been fulfilled. It was used in conventional Civic Education learning materials when viewed from the effectiveness of the language structure, has not been fulfilled because many students do not like it.

\section{Characteristics of Students}

Based on the analysis of student needs, it can be synthesized that students need Civic Education learning by using better learning materials. The teaching material in question must meet the criteria and characteristics of the student. Students are educated people who have a high tolerance value. Also, spread the value of diversity between groups. Students want Civic Education learning 
materials that are more contextual by the life of heterogeneous Indonesian people. That means that the students want to use multicultural-based Civic Education learning materials.

\section{Concept Mapping}

Multicultural-based Civic Education learning materials will have a positive impact on student learning processes and achievements. That can be reflected in students' enthusiasm in Figure 1 who want lectures by utilizing heterogeneous local culture as the primary foundation.

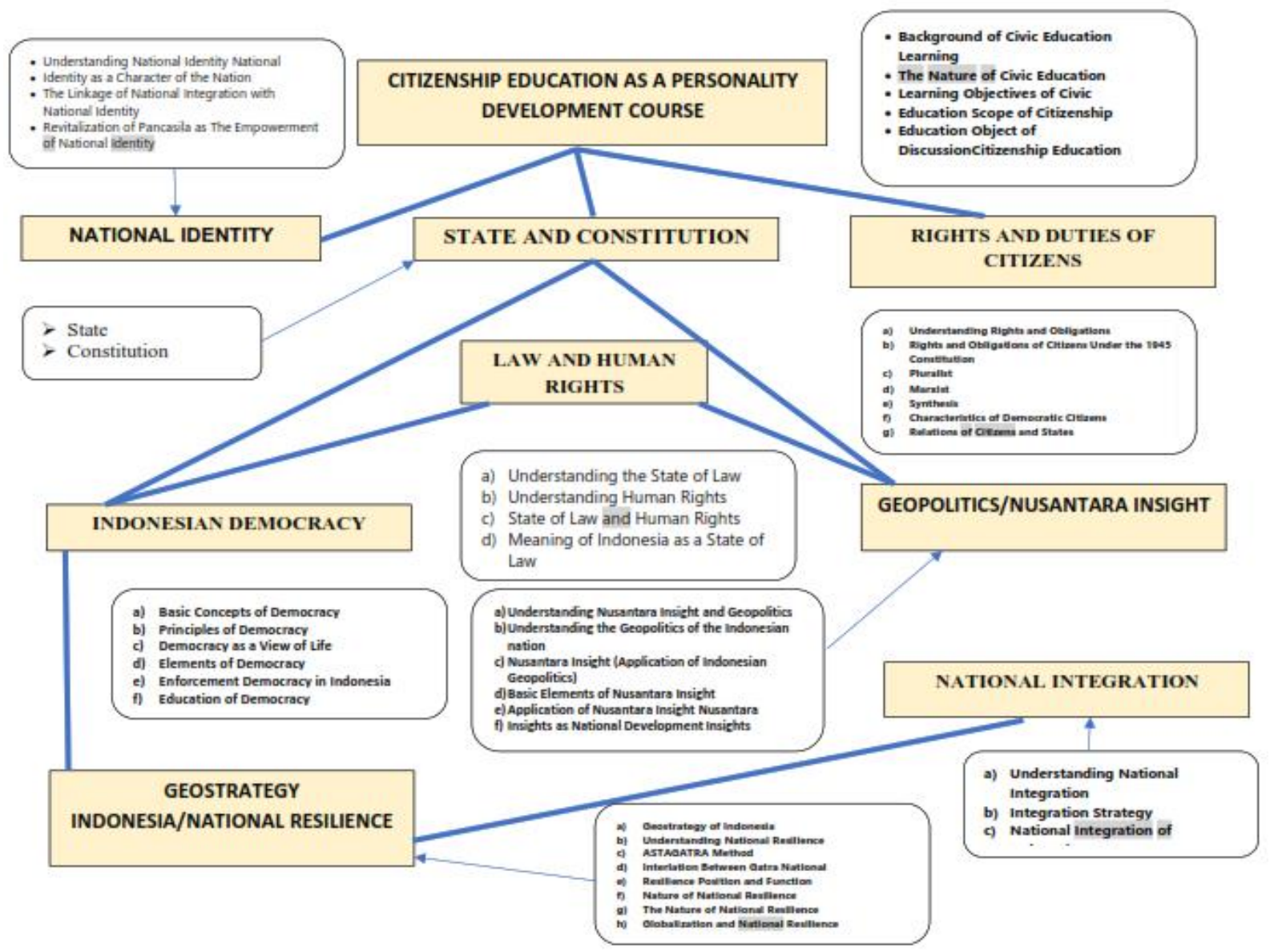

Figure 1 Concept Mapping of Civic Education

\section{Task. Analysis}

Based on the analysis of needs and concept maps, the results of task analysis can be presented in the form of learning objective specifications. The specification is to relax the tasks of peeling and understanding: Background of Civic Education Learning; The Nature of Civic Education; The Purpose of Civic Education Learning; Scope of Civic Education; Object of Discussion of Civic Education; Understanding National Identity; National Identity as the Character of the Nation; The Linkage of National Integration with National Identity; Revitalization of Pancasila as The Empowerment of National Identity; State and Nation; Constitution; Understanding Rights and Obligations; Rights and Obligations of Citizens Under the 1945 Constitution; Pluralist; Marxist; Synthesis; Characteristics of Democratic Citizens; Relations between Citizens and States; Basic Concepts of Democracy; Principles of Democracy; Democracy as a View of Life; Elements of Democracy Enforcement; Democracy in Indonesia; Democratic Education; Understanding the State of Law; Understanding Human Rights; States of Law and Human Rights; Meaning of 
Indonesia as a State of Law; Understanding of Nusantara Insight and Geopolitics; Understanding the Geopolitics of the Indonesian nation; Nusantara Insight (Application of Indonesian Geopolitics); Basic Elements of Nusantara Insight; Application of Nusantara Insights; Nusantara Insights as National Development Insights; Geostrategy Indonesia; Understanding National Resilience; Explaining about the Astagatra Method; Interlation among Gatras; Position and Function of the Conception of National Resilience; The Nature of National Resilience; The Nature of National Resilience; Globalization and National Resilience; Understanding National Integration; Integration Strategy; and National Integration of Indonesia.

\section{Design Stage}

In the design stage, the researchers made a blueprint. This stage produced is the formulation of learning goals that are SMAR (specific, measurable, applicable, and realistic). The right learning strategy to achieve these goals. Based on a map of learning concepts, objectives, and student characteristics, the right learning strategy is a multicultural-based Civic Education learning approach. Multicultural education is a policy in educational practice recognizing, accepting, and affirming human differences and equalities associated with gender, race, and class. Multiculturalism is a system of beliefs and behaviors that recognizes and respects all diverse groups within an organization or society, recognizes their distinct socio-cultures, and encourages and enables their continued contribution in an inclusive cultural context that empowers all in an organization or society.

\section{Development Stage}

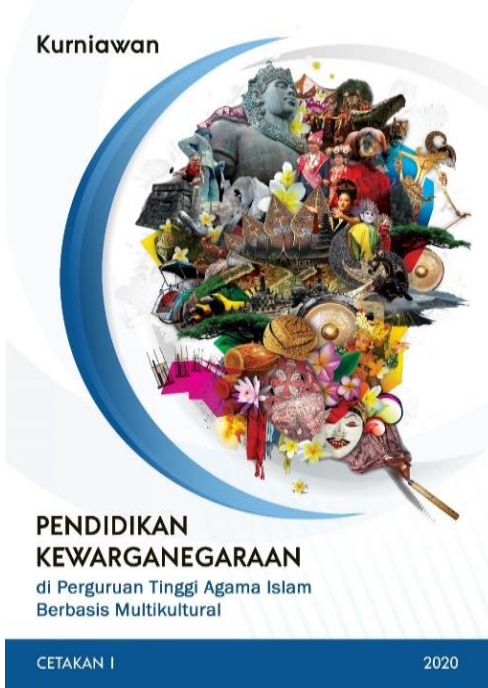

(a)

\section{BAB I}

PENDAHULUAN

A. Deskripsı Mata Kullah

Pendidkan Kewarganegaraan (PKn) menpekan matckulah pengenbangan kepribadan (MFK) yang MKWU (matekullah wajtb umum), agar mahasiswa dapat meningkatkan nllat-nilal kebangsaan dan nilat-nilat peradaban bangsa dan regara.

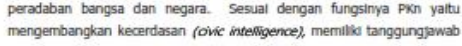

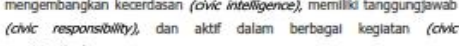
participation.

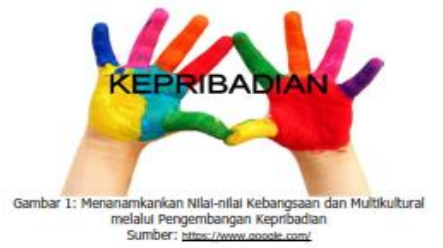

Beberapa materl yang akan dikembangkan dalam memperkuat nllalnilat kebangssan menuju masyarakat multkultural, antara laln; PKn

(b)
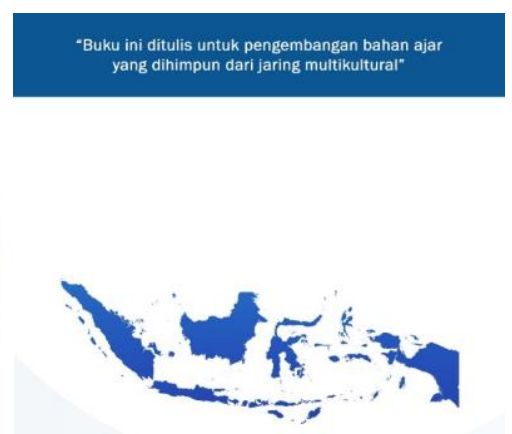

(c)

Figure 2. (a) Cover of Multicultural-based Civic Education Learning Materials, (b) Sample of Content-Format, and (c) Back cover

Development is the process of making a blueprint a reality at this stage developed multiculturalbased PKn teaching materials. The teaching materials are based on multicultural-based learning designs and strategies. Characteristics of teaching materials before revision are shown in Figure 2. 


\section{Implementation Stage}

\section{Experts Review}

Expert validation is carried out to determine the validity level of multicultural-based Civic Education learning materials. This stage is to get expert justification and review, then all the results of the design of multicultural-based Civic Education learning materials are validated by experts. There are 4 (four) validators in this expert review of learning materials. Based on validation results, we obtained a content validity rate of 4.14 with a correct category. Furthermore, the validity of the material with the learning model side was obtained that the validity level is very good with an average of 4.22 , but there is a revision of the validator that requires improvements to the cover, table of contents, and material format. The revision is more about multicultural content. This value is because the draft teaching materials do not reflect multicultural-based learning. The revised results are presented in Figure 3.

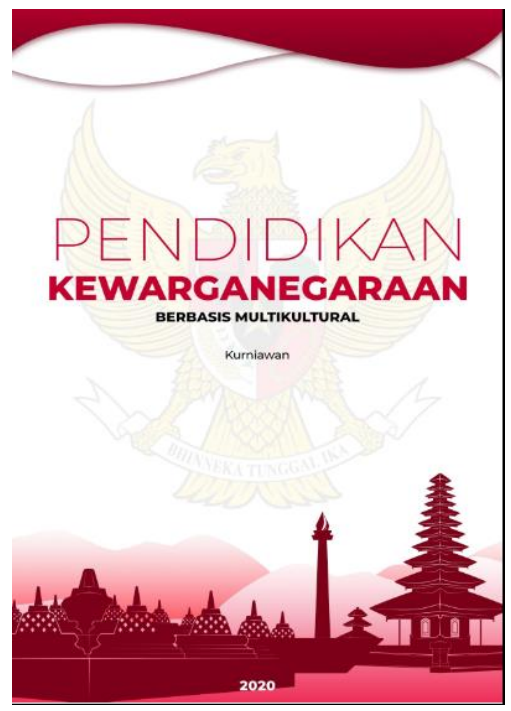

(a)

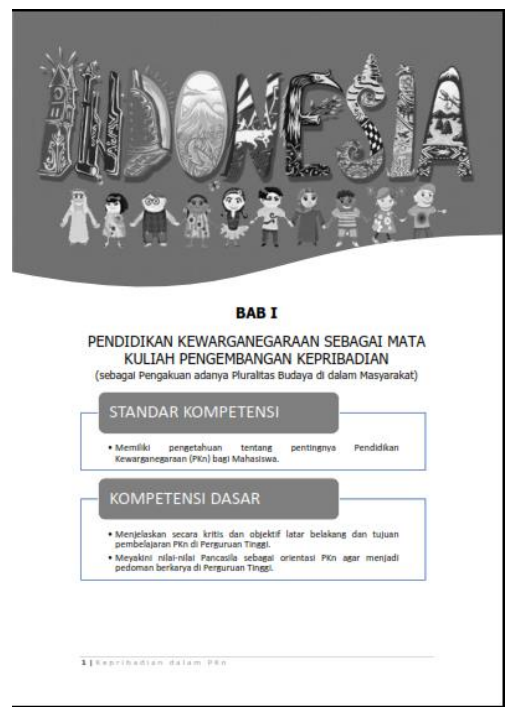

(b)

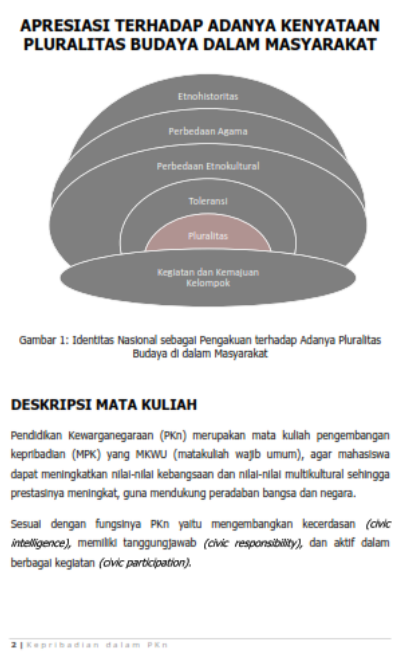

(c)

Figure 2. (a) Revision of Cover of Multicultural-based Civic Education Learning Materials, (b) \& (c) Revision of Content Format

\section{Evaluation Stage}

The evaluation phase of this study is carried out until the formative evaluation aims for revision needs. Based on the results of expert reviews and field trials that have been conducted in the following implementation stage, two stages of data analysis are qualitative and quantitative data analysis. Qualitative data analysis is used to process data in the form of inputs, criticisms, and suggestions from experts and field tests to continue to be carried out with gradual revisions for better media development. At the same time, the analysis of quantitative data is obtained from the respondents' assessment in the form of numbers on the given questionnaire. All of these evaluation stages aim for the feasibility of the final product. Worthy in terms of content, design, and user friendly. The validation/eligibility of content, in general, reached an average of 4.26, with the highest score of 5. This data means that multicultural-based Civic Education learning materials have very high validity. The validation of teaching material content based on multicultural content then obtained an average of 4.32 which means the validity level is very high. Next will be the results of practicality tests. 


\section{The practicality of Multicultural-based Civic Education Learning Materials}

The practical value of multicultural-based Civic Education learning materials in the classroom can be demonstrated by applying multicultural-based Civic Education learning materials in actual classes. Practicality is carried out in Teacher Education of Elementary School or Pendidikan Guru Madrasah Ibtidaiyah (PGMI) Studi Program at Faculty of Tarbiyah IAIN Curup in two limited classes (PGMI 1(P1), and PGMI 2 (P2)).

The results of assessing the practicality of multicultural-based Civic Education learning materials developed realized through the application of learning models in the classroom. Activity sheets and tests assess the practicality. Sheets in the application of multicultural-based Civic Education learning materials can be presented in the percentage column diagram of the implementation of activity sheets and test sheets for IAIN Curup students is that the implementation of student activity sheets as well as students. $\mathrm{r}=84.00 \%$, which states that the student worksheet can be carried out very practically. The same thing happened in the implementation of trials in the two IAIN Curup, consecutively implementing the exercise sheet by $85.00 \%$, implementing student activities by $85.50 \%$, and implementing the test by $84.00 \%$. These findings show that all components of the activity sheet and test sheet implementation for IAIN Curup are efficient (see Figure 4).

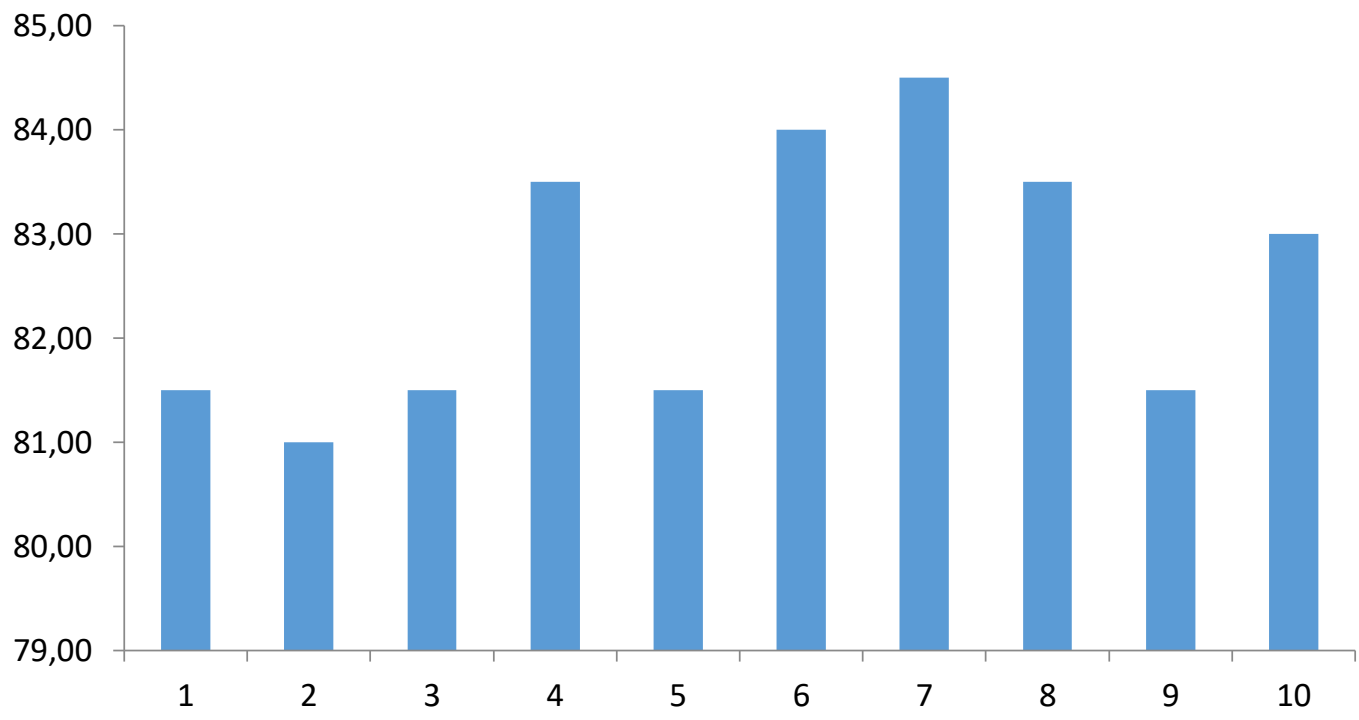

Figure 4. The practicality of Teaching Materials

\section{Information:}

1: The steps in the model can be implemented

2: Implementation of Learning Implementation Plan

3: The description of learning activities can be carried out

4: The description of group discussion activities can be carried out

5: The description of class discussion activities can be carried out

6: The description of training activities can be carried out

7: Lecturer acts as a guide in learning

8: The implementation of communication between students and students

9: The implementation of communication between lecturers and students

10: Implementation of cooperation between students and students in the learning process

Based on Figure 4, the practicality in implementing activity sheets and test sheets for P1 and $\mathrm{P} 2$ is that all aspects are efficient. It can be concluded that the practicality of multicultural- 
based Civic Education learning materials is efficient. Thus, it was very feasible to be applied in Civic Education learning at IAIN Curup.

\section{The Effectiveness of Multicultural-based Civic Education Learning Materials}

The research data was obtained from pretest and posttest on experiment and control groups. Pretest data collection aims to determine the initial ability of students. It aims to find out the posttest score of students after being given treatment. After taking pretest data, then continued with the treatment using multicultural-based Civic Education learning materials in the experimental group, while learning in the control group occurs conventionally. The learning process is carried out based on a lesson plan that researchers have previously designed. After being given treatment, a posttest was done on both groups. The descriptive data of the posttest can be seen in Table 1 .

Table 1. Descriptive data

\begin{tabular}{ccc}
\hline Statistics & Experiment Group & Control Group \\
\hline N Sample & 45 & 45 \\
\hline Mean & 78,444 & 55,222 \\
\hline Standard Deviation & 8,449 & 6,987 \\
\hline
\end{tabular}

Table 1 shows that the average learning achievement of the experimental group is more significant than the control group. It also presents the experimental and control groups' standard deviations, which are 8.449 and 6.987 , respectively.

Analysis of the effectiveness of multicultural-based teaching materials using analysis of covariance (ANCOVA). Inferential statistical analysis is done to analyze learning achievement data. The covariate variable in this study is the initial ability of students obtained from student pretest grades, while bound variables are student learning achievements obtained from posttest grades.

\section{Data Normality Test}

Based on data on the application of Civic Education learning with multicultural-based Civic Education learning materials, it can be tested the normality of the data obtained that $\mathrm{D}_{\mathrm{n}}=0.192$ with KS table $=0.203$. That suggests that $\mathrm{D}_{\mathrm{n}}<\mathrm{KS}$ Table, which means data on a normal distribution. Furthermore, data on a conventional group of Civic Education learning results can be obtained that $\mathrm{D}_{\mathrm{n}}=0.179$ with $\mathrm{KS}$ table $=0.203$. That suggests that $\mathrm{D}_{\mathrm{n}}<\mathrm{KS}$ Table, which means conventional group learning achievement data is usually distributed.

\section{Determining Regression Model}

Regression model $\mathrm{Y}=\mathrm{a}+\mathrm{bX}$, with $\mathrm{a}$ and $\mathrm{b}$ is estimation for ${ }_{\mathrm{q} 1}$ and $\theta_{2}$ of the equations $\mathrm{Y}=\theta_{1}+$ $\theta_{2} \mathrm{X}$. Based on the results of calculations of the regression model, the experimental group obtained the model equation $\mathrm{Y}=75.68+0.32 \mathrm{X}$. Based on the calculation of the regression model of the control group obtained the regression model equation $\mathrm{Y}=51.22+0.44 \mathrm{X}$.

\section{Independence Test}

The analysis for the independence test of the experimental class regression model is to a significant degree $=5 \%$ projected $\mathrm{F}(0.95 ; 1 ; 43)=4.08$ which means $\mathrm{F}^{*}=4.63>(0.95 ; 1 ; 43)$ then the coefficient of the regression model is not equal to zero. This data means that the student's initial ability (X) significantly influences the student's learning achievement $(\mathrm{Y})$. 
The analysis for the control class regression model independence test is that with a significant degree $=5 \%$ projected $\mathrm{F}(0.95 ; 1 ; 43)=4.08$ which means $\mathrm{F}^{*}=5.23>\mathrm{F}(0.95 ; 1 ; 43)$ then the coefficient of the regression model is not equal to zero. This data means that the student's initial ability $(\mathrm{X})$ significantly influences the student's learning achievement $(\mathrm{Y})$.

\section{Regression Model Linearity Test}

Based on the analysis of the linearity of the experimental class regression model, it was obtained that with a significant degree $=5 \%$ in the project $\mathrm{F}(0.95 ; 4 ; 39)=2.61$, which means $\mathrm{F}^{*}=0.85<2.61=$ $\mathrm{F}(0.95 ; 4 ; 39)$ then the coefficient of the regression model of the experimental class is linear. This data means that the relationship between the student's initial ability and learning achievements is linear.

Based on linearity analysis the control class regression model obtained that with a significant degree $=5 \%$ in the project $\mathrm{F}(0.95 ; 4 ; 39)=2.61$ which means $\mathrm{F}^{*}=1.19>\mathrm{F}(0.95 ; 4 ; 39)$ then the coefficient regression model of the control class is linear. This data means that the relationship between the student's initial ability and learning achievements is linear. Since the experimental and control class data are linear, it continues with the next test. $\alpha$

\section{Parallel Test of Two Regression Models}

Since the two regression models are not the same, it will be continued by testing the alignment of the regression coefficient. Based on the results of the parallel regression model of the experimental and the control groups obtained, the analysis results are $\mathrm{A}=4762.31 ; \mathrm{B}=4893.33$; and $\mathrm{F}^{*}=2.37$. Using a significant level $=5 \%$ projected $\mathrm{F}(0.95 ; 1 ; 86)=4.00$ which means $\mathrm{F}^{*}>\mathrm{F}(0.95 ; 1 ; 86)$, then Ho was rejected. This data means linear regression models of experimental and parallel control groups.

Because all variance analysis has been fulfilled and the two regression models are parallel, it can be concluded that there are differences in student learning achievements in the experimental group that are given learning with multicultural-based Civic Education learning materials and the results of learning control group with conventional learning materials.

\section{Test the Similarity of Two Regression Models}

Based on the results of the calculation of the similarity test of two experimental group regression models and control group obtained linear regression models of combined data with $a=-157.52$ and $\mathrm{b}=16.18$, then the combined linear regression can be obtained equations: $\mathrm{Y}=-157.52+16.18$ $\mathrm{X}$, and $\mathrm{F}^{*}=4235.2$. Using a significant level $=5 \%$ projected $\mathrm{F}(0.95 ; 2 ; 86)=3.15$ which means $F^{*}=4235.2>\mathrm{F}(0.95 ; 2 ; 86)$, Ho was rejected. This data means that the linear regression model of the experimental and the control groups are not the same. This data means that there are significant differences in the learning achievements of students taught with multicultural-based Civic Education learning materials and that are taught conventionally.

To determine which is better between the two can be determined through the regression line, the experimental group regression equation is $\mathrm{Y}=75.68+0.32 \mathrm{X}$, and the regression equation control group is $\mathrm{Y}=51.22+0.44 \mathrm{X}$. The regression lines are aligned, and hence enough to be disputed the regression line constants for the experimental and control groups. The experimental group regression line constant is 75.86 greater than the constant for the control group of 51.22. This data means that Civic Education students who are taught with multicultural-based Civic Education learning materials are better than conventionally taught students. 
Thus, the multicultural-based Civic Education learning materials have met the criteria of validity, practicality, and effectiveness. In other words, multicultural-based Civic Education learning materials have met a high level of validity based on expert tests and empiric tests, a high level of practicality based on expert tests and empiric tests, and a high level of effectiveness based on expert tests and empiric tests. The researchers conclude that student learning achievements taught with multicultural-based Civic Education learning materials are better than conventionally taught students.

\section{DISCUSSION}

This research shows that multicultural-based Civic Education learning materials are valid, practical, and effective in improving student learning achievements. These findings support some previous research. Students are increasing in observing a case, and there is no tendency in certain groups (Utami \& Cahyono, 2018). The study results also stated that students independently had conducted literacy search activities in problem-solving, lecturers only as facilitators. Democratically, students convey problem solutions and provide the same opportunities as other students without seeing the dominant culture in the classroom. Also, the activity of students with intergroup is still lacking. Student activeness is still dominant in small groups only.

The effort develops students' ability to perceive different cultures and be optimistic about cultural, racial, and ethnic differences (Rochana, 2020). Multicultural-based education increases national and personality insights, such as religious, historical, psychological, socio-cultural, and geographical foundations (Hifza et al., 2020) (Syahrul, 2021). Multicultural-based learning must be done through practical learning and active learning concerning the religious diversity of students (Syahbudin \&Hanafi, 2018). Implement multicultural-based coaching implemented with the integration of content or material dimension; construction of knowledge dimension; reduction of prejudice dimension, fair education dimension, and empowerment of school culture and social structure dimension (Feli et al., 2019). Multicultural-based education is a conscious effort to develop the personality of society. It was to educate them from various social statuses, races, tribes, and religions. Multicultural-based education is an attempt to create a good and intelligent personality in the face of problems related to cultural diversity (Marhayani et al., 2017). Thus, we have been convinced that multicultural-based learning for students can improve national values and improve their learning achievements.

\section{CONCLUSION}

Multicultural-based Civic Education learning materials have a positive impact on students. The learning achievement of students taught with these teaching materials is better than students who are taught conventionally. The result is that multicultural-based Civic Education learning materials have met a high level of validity, practicality, and effectiveness to improve students' learning achievements.

\section{REFERENCE}

Endah, N. U. R. (2016). the Religious Character Education Through Religious Activities in State Junior High School 2 of Sumbang, Banyumas Study Program of Islamic Education Faculty of Tarbiya and Teacher Training State Institute of Islamic Studies Purwokerto. 
Feli, N. F., Islam, S., \& Jadid, U.N. (2019). Implementation of Multicultural Based Learning in Improving Student Learning Achievement. MUD ARRISUNA Journal, 9(1), 152-169.

Hadiwijaya, M., \& Adi, A. (2018). Multicultural Based Learning in Increasing Students' Tolerance Attitude. JOURNEY (Journal of English Language and Pedagogy), 1(1), 23-31. https://doi.org/10.33503/journey.v1i1.219

Hifza, H., Antoni, A., Shakhrani, A. W., \& Hartati, Z. (2020). The Multicultural Islamic Education Development Strategy on Educational Institutions. Iqra's Journal: The Study of Educational Sciences, 5(1), 158-170. https://doi.org/10.25217/ji.v5i1.799

Marhayani, D. A., Kariadi, D., \& Yanti, L. (2017). Multicultural-Based Education as an Effort of Conflict Prevention for Cidayuma Society In Singkawang. Journal of Education and Teaching, 50(1), 28-35. Retrieved from https://ejournal.undiksha.ac.id/index.php/JPP/article/view/10090

Muslichah, M. (2018). a Model Integrating Cultural Diversity Education Into the Accounting Curriculum in Higher Institution. Wiga: Journal of Economic Research, 7(1), 48-56. https://doi.org/10.30741/wiga.v7i1.333

Plomp, T., \& Nieveen, N. (2013). Educational Design Research Educational Design Research. Educational Design Research, (July), 1-206. https://doi.org/10.1007/978-1-4614-3185-5_11

Rochana, T. (2020). The Implementation of Multicultural-Based Sociology Learning in Senior High. Community: International Journal of Indonesian Society and Culture, 12(2), 288-297. https://doi.org/10.15294/komunitas.v12i2.23338

Shahbudin, Z., \& Hanafi, M. (2018). The Model of Learning Design based on Islamic Multicultural Education to Prevent Conflicts of Behavior. Journal of IslamicEducation, 3(2), 155. https://doi.org/10.15575/jpi.v3i2.1279

Syahrul, S. (2021). Integrating Pluralism and Multicultural Education to Prevent Radicalism at Muhammadiyah University of Kupang. Education: Journal of Islamic Education Research, 16(1), 1-14. https://doi.org/10.21043/edukasia.v16i1.8285

Thoriquttyas, T., \& Rohmawati, N. (2017). Amplifying The Character Education And The Multiculturalism For a Nationalism Building. TADRIS: Journal of IslamicEducation, 12(2), 134-145. Retrieved from http://ojs3.iainmadura.ac.id/index.php/tadris/article/view/1391

Utami, P. S., \& Cahyono, H. (2018). Implementation of Multicultural-Based Education Through Problem Based Learning Model in Students of PPKn Study Program Muhammadiyah Ponorogo University. Journal of Dimensions of Education and Learning, 6(1), 8-14. Retrieved from http://journal.umpo.ac.id/index.php/dimensi/article/view/817

Wahab, R. (2007). Multicultural Education: Its Implication For General Education And Gifted Education In Indonesia. In International Conference: Said Nursi on Multicultural Education-for Renewal of Faith and Civilization in the Contemporary World, on May, 1-14.

Widada, W., Herawaty, D., Falaq, A., Anggoro, D., Yudha, A., \& Hayati, M. K. (2019). Ethnomathematics and Outdoor Learning to Improve Problem Solving Ability. Advances in Social Science, Education and Humanities Research, Volume 295, 295(ICETeP 2018), 13-16. 


\section{AUTHORS CONTRIBUTION}

\begin{tabular}{|l|l|}
\hline \multicolumn{1}{|c|}{ Author } & \multicolumn{1}{c|}{ Contribution } \\
\hline Kurniawan & $\begin{array}{l}\text { Provide writing ideas, writing guidance, complete the } \\
\text { writing of the article, and the corresponding author }\end{array}$ \\
\hline Wachidi & \begin{tabular}{l} 
Check and complete the writing of the article \\
\hline Turdjai
\end{tabular} \\
\hline Wasidi & $\begin{array}{l}\text { Translate, check grammar and revise the article } \\
\text { Chalysis. }\end{array}$ \\
\hline
\end{tabular}

